\title{
CBIR Penyakit Kulit dengan Metode Co-Occurrence Matrix dan Color Moments
}

\author{
Ni Putu Chendy Widya Santi D, I Ketut Gede Darma Putra, I Made Sunia Raharja \\ Program Studi Teknologi Informasi Universitas Udayana \\ Bukit Jimbaran, Bali, Indonesia, telp. (0361) 701806 \\ e-mail : chendywidyasanti@gmail.com, ikgdarmaputra@unud.ac.id, sunia.raharja@unud.ac.id
}

\begin{abstract}
Abstrak
Content Based Image Retrieval (CBIR) adalah sebuah teknik pencarian citra dari database berdasarkan informasi citra yang dikembangkan karena pencarian teknik berbasis teks dinilai kurang efektif dalam merepresentasikan informasi citra. CBIR citra penyakit kulit pada penelitian ini menggunakan 12 sample citra penyakit kulit seperti Acne, Acropustulosis, Alopecia, Dermatitis, Hemangioma, Herpes, Ichtyosis, Molluscum, Nummular, Skin Tag, Urticaria, dan Vitiligo. Metode yang digunakan adalah untuk mengekstraksi fitur tekstur dan fitur warna dari suatu citra penyakit kulit. Fitur tekstur diekstraksi menggunakan Co-occurrence Matrix untuk analisa ekstraksi dengan atribut yang dihitung yaitu nilai energy, contrast, entropy, homogeneity, dan correlation sehingga menghasilkan vektor ciri tekstur. Ekstraksi fitur warna menggunakan Color Moments untuk menghitung ruang warna menggunakan tiga momen yang menghasilkan vektor ciri warna dari distribusi warna citra yaitu mean, standard deviation, dan skewness. Hasil perbandingan perhitungan kemiripan (similarity computation) dari kedua metode menghasilkan akurasi lebih tinggi dengan Metode Color Moments daripada Metode Cooccurrence Matrix untuk citra penyakit kulit.
\end{abstract}

Kata Kunci : Content Based Image Retrieval, Co-occurrence Matrix, Color Moments, Citra Penyakit Kulit.

\begin{abstract}
Content Based Image Retrieval (CBIR) is a technique for searching images from database based on information from the image which developed because the technique based on text-based is less effective for represent an image. CBIR skin disease in this research use 12 sample of skin disease images such as Acne, Acropustulosis, Alopecia, Dermatitis, Hemangioma, Herpes, Ichtyosis, Molluscum, Nummular, Skin Tag, Urticaria, and Vitiligo. Method use for this research is for extraction texture feature and color feature from a skin disease image. Texture feature is using co-occurrence Matrix which compute energy, contrast, entropy, homogeneity, and correlation until vector texture result. Extraction color use color moments to compute color space using three moments which result color feature from color distributions such as mean, standard deviation, and skewness. Final result showed the combination of similarity computation of two methods is the acuration of Color Moments method is more robust than Co-occurrence Matrix Method for skin disease images.
\end{abstract}

Keywords : Content Based Image Retrieval, Co-Occurrence Matrix, Color Moments, Skin Disease Images.

\section{Pendahuluan}

Kulit adalah suatu organ terluar dari tubuh yang melapisi seluruh tubuh manusia. Salah satu fungsi kulit adalah pelindung tubuh pertama kali dari benda asing yang masuk ke dalam tubuh. Penyakit kulit dapat menyerang siapa saja tidak mengenal usia dan dapat menyerang di bagian tubuh mana saja. Penyakit kulit menjadi sangat marak di kalangan masyarakat di berbagai tingkatan di Indonesia [1]. Informasi penyakit kulit dapat diperoleh tidak hanya terbatas pada data nonvisual (teks dan suara), namun juga dalam bentuk visual (citra dan video). Citra sebagai salah satu komponen multimedia memegang peranan sangat penting sebagai bentuk informasi visual [2]. Teknik yang digunakan untuk menghindari pemakaian deskripsi secara

CBIR Penyakit Kulit dengan Metode Co-occurrence Matrix dan Color Moments (Ni Putu Chendy Widya Santi D) 
tekstual adalah dengan Content Based Image Retrieval (CBIR). CBIR yaitu suatu metodologi untuk pemanggilan kembali atau pencarian data citra berdasarkan konten citra [3]

CBIR Penyakit Kulit dengan Metode Co-occurrence Matrix dan Metode Color Moments pada penelitian ini dikembangkan menggunakan citra penyakit kulit dengan pemilihan fitur tekstur dan fitur warna untuk merepresentasikan isi dari citra penyakit kulit. Fitur tekstur (texture) merupakan salah satu ciri yang menggambarkan pola yang berulang pada piksel dalam citra [4]. Metode yang dapat digunakan untuk mengekstraksi fitur tekstur adalah dengan melakukan perhitungan Co-occurrence Matrix, kemudian dilakukan analisa ektraksi dengan atribut energy, contrast, entropy, homogeneity, dan correlation.

Fitur warna juga merupakan salah satu ciri visual yang baik digunakan dalam Content Based Image Retrieval (CBIR). Warna dianggap memiliki hubungan yang kuat dengan objek dalam suatu citra. Metode Color Moments mampu melakukan ekstraksi fitur warna tanpa dipengaruhi masalah perbedaan pencahayaan dan perbedaan ukuran citra. Proses ekstraksi pada Metode Color Moments menggunakan tiga momen utama dari distribusi warna citra, yaitu mean, standard deviation, dan skewness [5].

\section{Metodologi Penelitian}

Metodologi Penelitian merupakan tahap-tahap yang digunakan untuk melakukan penelitian ini. Tahapan-tahapan penelitian dari aplikasi pintar pencarian gambar penyakit kulit dengan Metode Co-occurrence Matrix dan Metode Color Moments dapat dilihat pada Gambar 1 berupa alur penelitian.

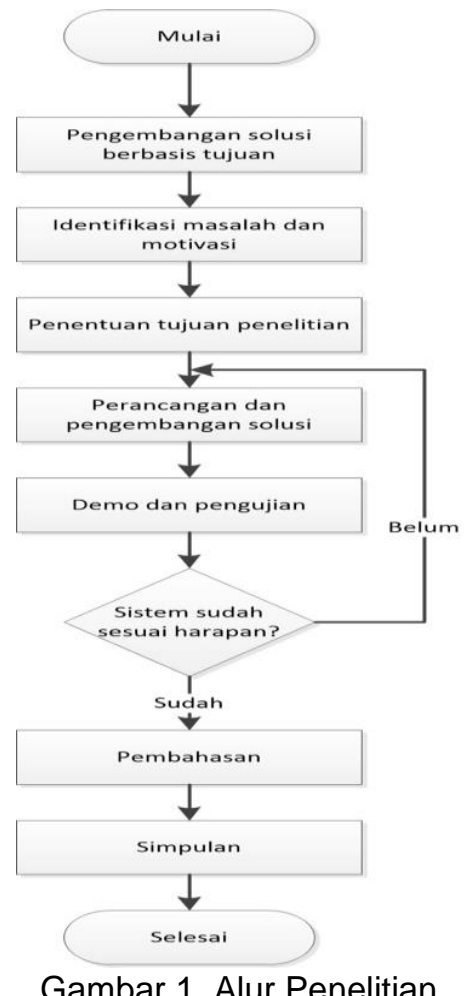

Alur penelitian dalam perancangan sistem digunakan berdasarkan Metode DSRM (Design Science Research Methodology). Alur penelitian yang didasarkan pada Metode DSRM adalah sebagai berikut.

1. Pendefinisian masalah dari sistem yang dibuat.

2. Pengumpulan dan studi literatur yang berhubungan dengan Content Based Image Retrieval pada Citra Penyakit Kulit dengan Metode Co-occurrence Matrix dan Metode Color Moments.

3. Mempelajari dan memahami proses-proses dalam Content Based Image Retrieval pada Citra Penyakit Kulit dengan Metode Co-occurrence Matrix dan Metode Color Moments. 
4. Perancangan basis data, bagian dari prototype Content Based Image Retrieval pada Citra Penyakit Kulit dengan Metode Co-occurrence Matrix dan Metode Color Moments.

5. Pengujuan prototype dan analisis hasil pengujian sistem.

6. Pengambilan kesimpulan dari pengujian dan analisa yang dilakukan serta pembuatan laporan hasil penelitian.

\subsection{Gambaran Umum}

Gambaran umum proses keseluruhan sistem CBIR yang dibangun terdiri dari dua proses yaitu data insertion dan query processing. Gambar 2 merupakan tahapan proses yang dimulai dari proses input hingga proses output.

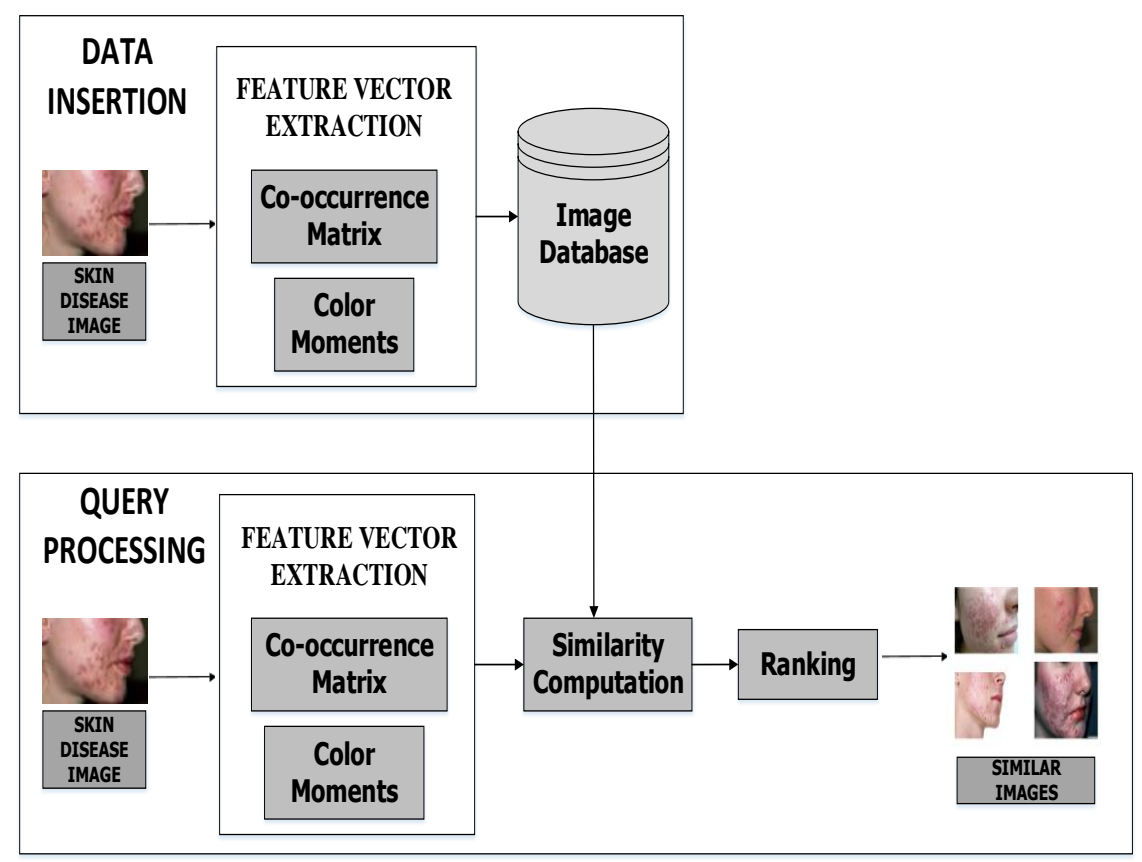

Gambar 2. Gambaran Umum

Gambar 2 menunjukkan gambaran umum dari sistem CBIR penyakit kulit dengan Metode Co-occurrence Matrix dan Color Moments. Gambaran umum terdiri dari dua proses utama yaitu data insertion dan query processing. Data Insertion dimulai dari semua citra penyakit kulit dikonversi ke HSV dalam sistem kemudian diekstrasi menggunakan Metode Cooccurrence Matrix dan Metode Color Moments. Citra penyakit kulit yang telah diekstraksi, nilainya disimpan dalam pemodelan basis pengetahuan. Tahap Query Processing adalah tahap selanjutnya setelah proses Data Insertion, pada tahap ini citra query dari salah satu citra penyakit kulit diuji menggunakan kedua metode. Tahap Query Processing dimulai dari menginput-kan citra query yang diekstrasi dengan Metode Co-occurrence Matrix dan Metode Color Moments selanjutnya dicocokkan dan dicari kemiripan citra query dengan nilai basis pengetahuan yang telah disimpan sebelumnya. Hasil pencocokan kemiripan dalam sistem (similarity computation) kemudian diranking dan menghasilkan citra yang mirip dengan citra query (similar images). 


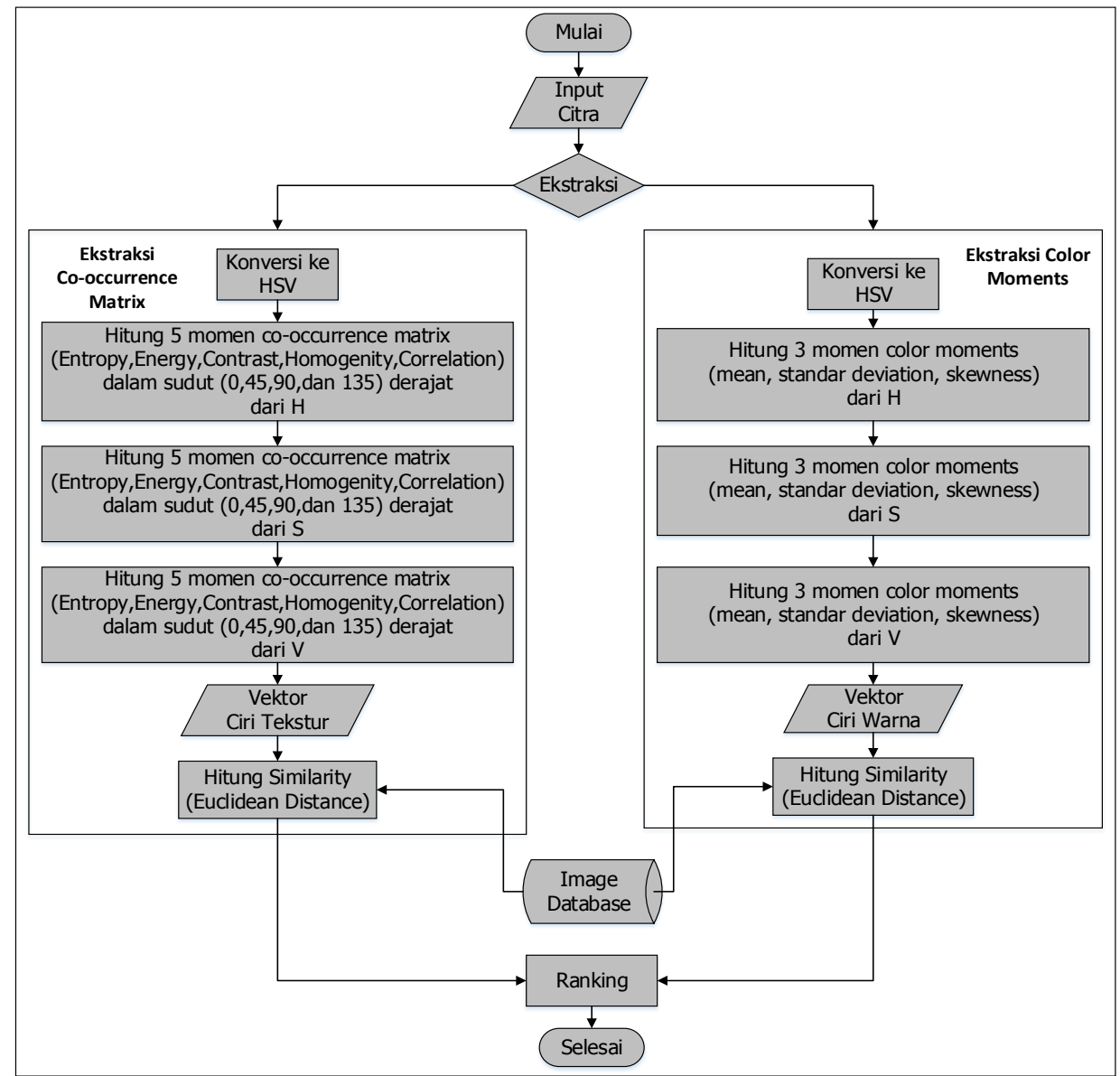

Gambar 3. Flowchart sistem CBIR

Gambar 3 merupakan flowchart atau alur dari sistem CBIR penyakit kulit dengan Metode Co-occurrence Matrix dan Metode Color Moments. Flowchart dapat dideskripsikan sebagai berikut:

1. Pra-proses

Pra-proses merupakan tahap awal yang ditandai dengan membaca matriks citra yang di-input-kan pada proses Data Insertion dan Query Processing kemudian mengubah citra menjadi HSV yang dimanfaatkan untuk tahap ekstraksi fitur.

2. Ekstraksi Fitur

Sistem menangani ekstraksi fitur tekstur citra menggunakan Metode Co-occurrence Matrix dan menangani ekstraksi fitur warna citra menggunakan Metode Color Moments.

3. Perhitungan Similarity

Sistem dapat melakukan proses similarity computation antara citra query dengan citra database. Proses similarity computation yang digunakan dalam sistem menggunakan fungsi similarity yaitu euclidean distance. Euclidean distance digunakan untuk menghitung jarak kemiripan antara hasil ekstraksi tekstur dan warna citra query dengan citra database.

4. Perangkingan

Sistem Content Based Image Retrieval pada Citra Penyakit Kulit dengan Metode Cooccurrence Matrix dan Metode Color Moments dapat mengurutkan citra hasil dari

5. Akurasi Sistem distance yang paling rendah sampai distance yang paling tinggi.

Sistem Content Based Image Retrieval pada Citra Penyakit Kulit dengan Metode Cooccurrence Matrix dan Metode Color Moments dapat menghitung keakurasian sistem yang diperoleh melalui perbandingan citra yang dikenali dengan keseluruhan citra yang diuji. 


\section{Kajian Pustaka}

Bab kajian pustaka membahas mengenai dasar-dasar teori penunjang yang didapatkan dari buku atau internet maupun jurnal yang menunjang dalam pembuatan penelitian.

\subsection{Content Based Image Retrieval System (CBIR)}

Content Based Image Retrieval (CBIR) adalah salah satu metodologi untuk pemanggilan kembali data citra berdasarkan content sebuah citra [6]. Sistem menggunakan suatu algoritma image processing dalam mengekstraksi fitur yang direpresentasikan oleh citra seperti warna, tekstur, dan bentuk. Keuntungan utama dari pendekatan CBIR adalah proses retrieval dilakukan secara otomatis oleh sistem komputer. Kekurangan dari Content Based Image Retrieval adalah terdapat keterbasan alat capture data sehingga data tidak dapat menggambarkan seluruh keadaan yang sebenarnya atau dikenal dengan istilah sensory gap [7].

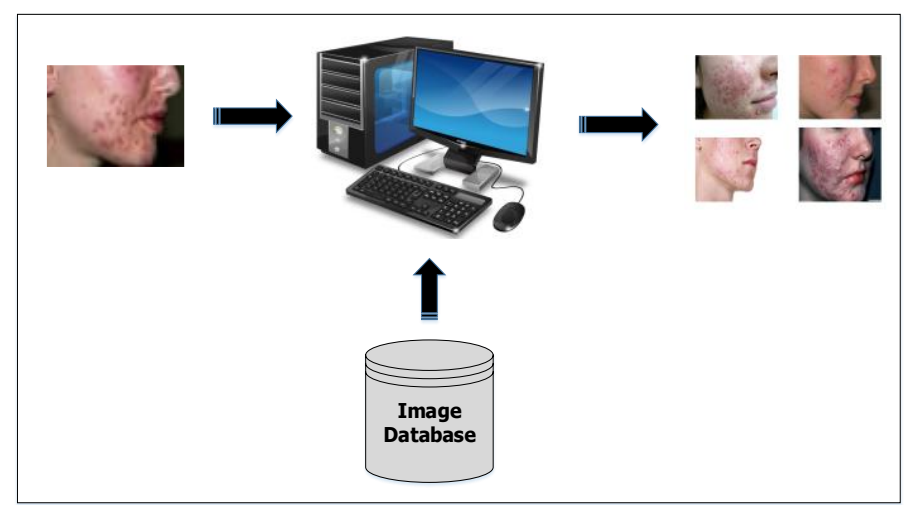

Gambar 4. Content Based Image Retrieval System

\subsection{Co-occurrence Matrix}

Co-occurrence Matrix mempunyai sekumpulan informasi tentang derajat keabuan (intensitas) suatu piksel dengan tetangganya pada jarak dan orientasi yang tepat. Matriks Cooccurrence adalah matriks yang dibangun menggunakan histogram tingkat kedua. Matriks ini berukuran $L x L$, dimana $L$ menyatakan banyaknya tingkat keabuan, dengan elemen $P\left(x_{1}, x_{2}\right)$ yang merupakan distribusi probabilitas bersama dari pasangan titik-titik dengan tingkat keabuan $x_{1}$ yang berlokasi pada koordinat $(j, k)$ dan $x_{2}$ yang berlokasi pada koordinat $(m, n)$. Koordinat pasangan titik-titik berjarak $r$ dengan sudut $\theta[8]$.

\section{Entropy}

$f_{1}=\sum_{i} \sum_{j} P_{i, j}\left(-\ln P_{i, j}\right)$

Energy

$f_{2}=\Sigma_{i} \Sigma_{j}\{p(i, j)\}^{2}$

Contrast

$\mathrm{f}_{3}=\sum_{i, j=0}^{n-1} P i, j(i-j)^{2}$

Homogenity

$f_{4}=\sum_{i} \sum_{j} \frac{1}{1+(i-j)^{2}} p(i, j)$

Correlation

$f_{5}=\frac{\Sigma_{i} \Sigma_{j}(i j) p(i, j)-\mu_{x} \mu_{y}}{\sigma_{x} \sigma_{y}}$

\subsection{Color Moments}

CBIR Penyakit Kulit dengan Metode Co-occurrence Matrix dan Color Moments (Ni Putu Chendy Widya Santi D) 
Color Moments adalah suatu metode yang digunakan untuk membedakan citra berdasarkan fitur warnanya. Dasar dari Metode Color Moments adalah asumsi bahwa distribusi warna pada sebuah citra dapat dinyatakan sebagai distribusi probabilitas, oleh sebab itu, akurasi yang dihasilkan adalah konstan walaupun ukuran citra berubah [9].

Mean

$\mathrm{E}=\frac{1}{N} \sum_{j=0}^{N} P_{i j}$

Standar Deviation

$\sigma_{i}=\sqrt{\left(\frac{1}{\mathbb{N}} \sum_{j=1}^{\mathbb{N}}\left(P_{i j}-E_{i}\right)^{2}\right)}$

Skewness

$S_{i}=\sqrt[s]{\left(\frac{1}{\mathbb{N}} \sum_{j=1}^{N}\left(P_{i j}-E_{i}\right)^{3}\right)}$

\subsection{Penyakit Kulit}

Penyakit kulit adalah suatu penyakit yang berhubungan dengan jaringan penutup permukaan tubuh. Penyakit kulit meskipun bersifat ringan, apabila tidak ditangani secara serius, maka dapat memperburuk kondisi kesehatan penderita karena kulit manusia tidak steril, maka bakteri dapat bertindak sebagai parasit yang dapat menimbulkan penyakit kulit. Penyakit kulit dapat disebabkan oleh bakteri dan virus yang mengkontaminasi kulit dapat hidup dan bermultiplikasi. Frekuensi kontaminasi menimbulkan penyakit infeksi. Faktor utama terserang penyakit kulit karena kurangnya memperhatikan kesehatan atau kebersihan kulit dan juga dipengaruhi oleh tingkat kekebalan tubuh, mengabaikan serta kurang memahami penyebabpenyebab terjadinya penyakit kulit. Citra penyakit kulit yang digunakan dalam penelitian ini menggunakan ruang warna Hue Saturation Value (HSV) karena warna Hue berdasar pada Human Perseption. Model warna HSV merupakan model warna yang diturunkan dari model warna RGB yang diperoleh melalui proses konversi warna dari RGB ke HSV [10].

Tabel 1. Penyakit Kulit

\begin{tabular}{|c|c|c|}
\hline No. & Gambar & Nama Penyakit \\
\hline 1. & & Acne \\
\hline 2. & & Acropustulosis \\
\hline 3. & & Alopecia \\
\hline 4. & & Dermatitis \\
\hline 5. & & Hemangioma \\
\hline 6. & & Ichtyosis \\
\hline
\end{tabular}

CBIR Penyakit Kulit dengan Metode Co-occurrence Matrix dan Color Moments (Ni Putu Chendy Widya Santi D) 


\begin{tabular}{lc}
\hline 7. & Molluscum \\
8. & Nummular \\
9. & Urticaria \\
10. & Vitiligo \\
& \\
\hline
\end{tabular}

\section{Hasil dan Pembahasan}

Bab hasil dan pembahasan membahas mengenai citra penyakit kulit, antarmuka sistem, dan hasil pengujian sistem yang telah dilakukan.

\subsection{Dataset}

Pengujian pada penelitian CBIR penyakit kulit menggunakan dataset citra penyakit kulit. Dataset yang digunakan terdiri dari data citra latih dan data citra uji. Citra yang digunakan berukuran 128x128 piksel dengan format PNG.

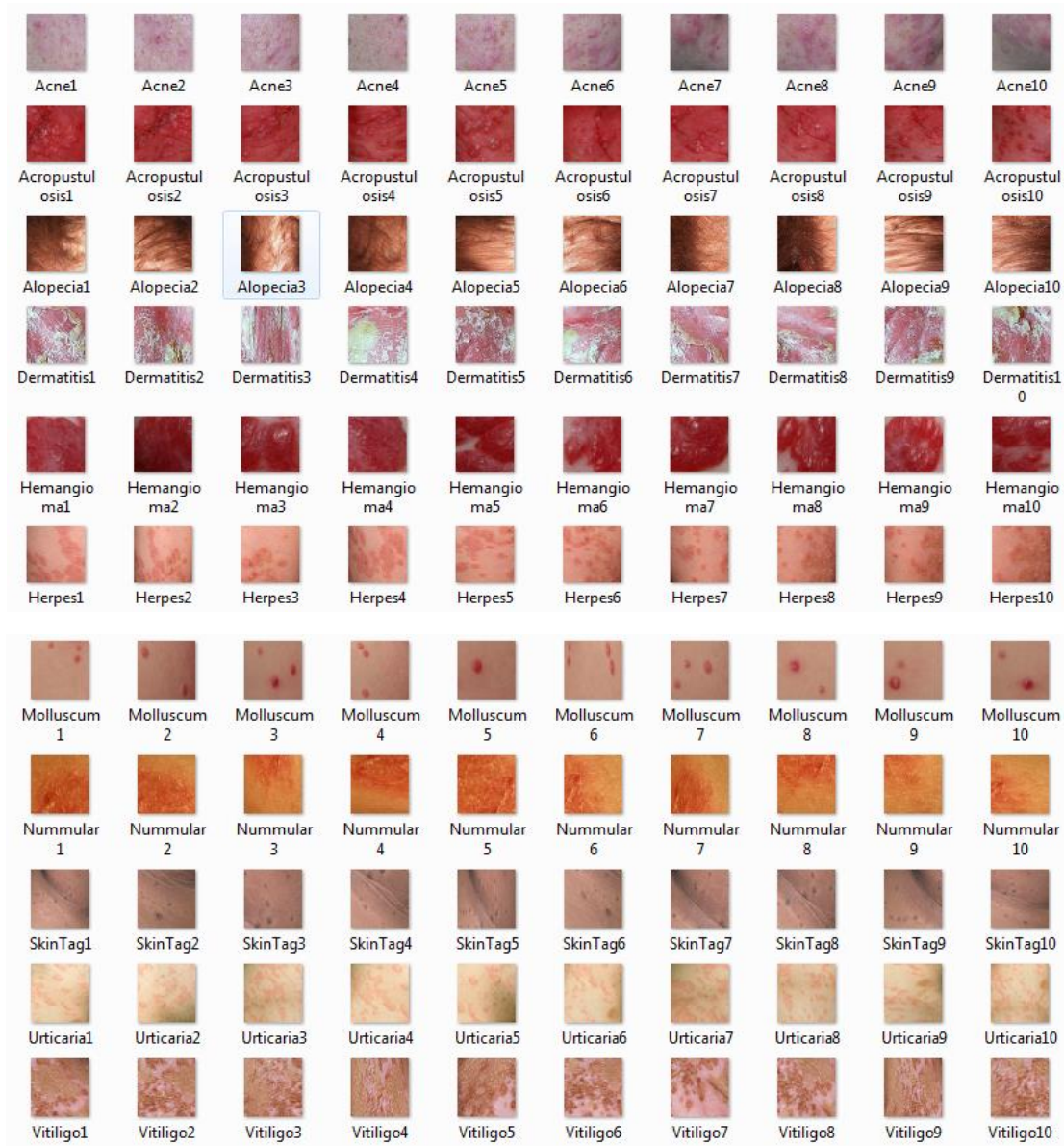


Gambar 5. Citra Latih

Gambar 5 merupakan citra latih yang digunakan dalam sistem CBIR penyakit kulit. Citra data latih berjumlah 120 citra penyakit kulit dari 12 kelas dengan masing-masing 10 sampel. Kelas penyakit kulit yang digunakan diantaranya Acne, Acropustulosis, Alopecia, Dermatitis, Hemangioma, Herpes, Ichtyosis, Molluscum, Nummular, Skin Tag, Urticaria, dan Vitiligo. Citra data uji penyakit kulit keseluruhan berjumlah 48 citra menggunakan 4 sample citra penyakit kulit pada tiap kelasnya yang dapat dilihat pada Gambar 6.

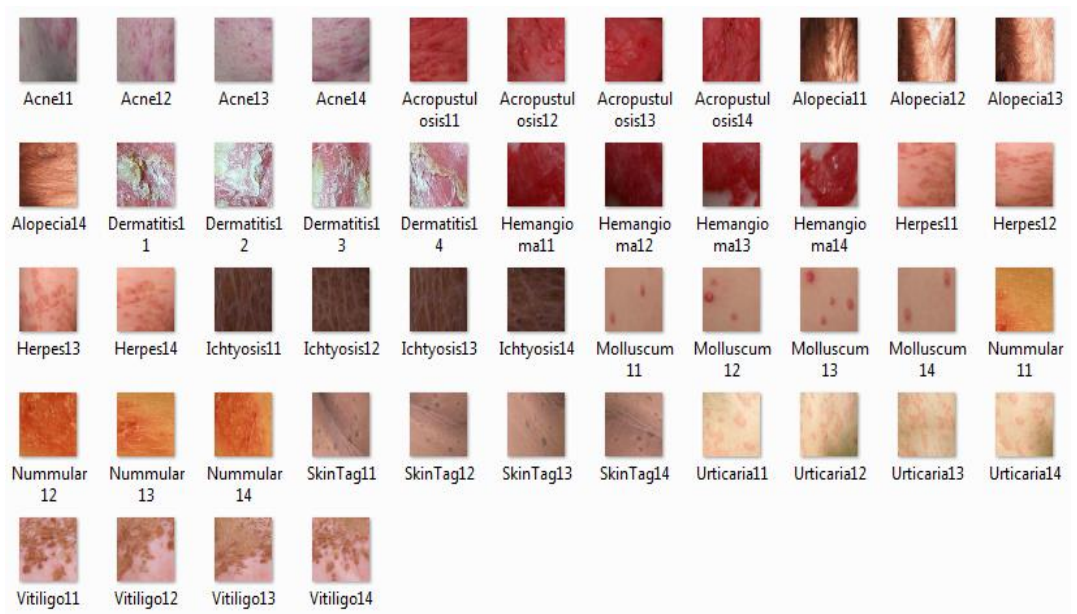

Gambar 6. Citra Uji

\subsection{Antarmuka Sistem}

Antarmuka sistem merupakan tampilan dari sistem CBIR penyakit kulit. Beberapa hasil pengujian pada kedua metode ditampilkan dengan beberapa screenshoot seperti pada Gambar $7 a$ dan $7 b$.

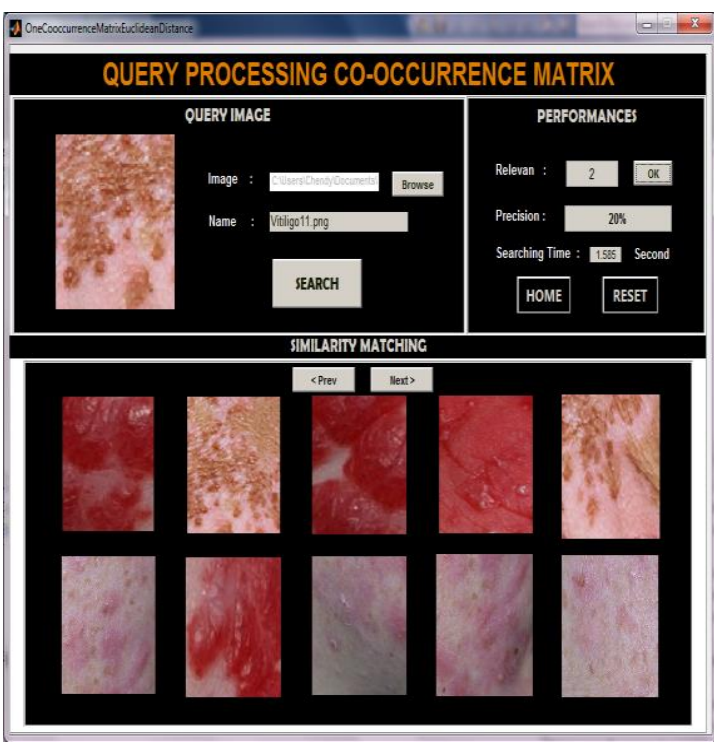

(a)

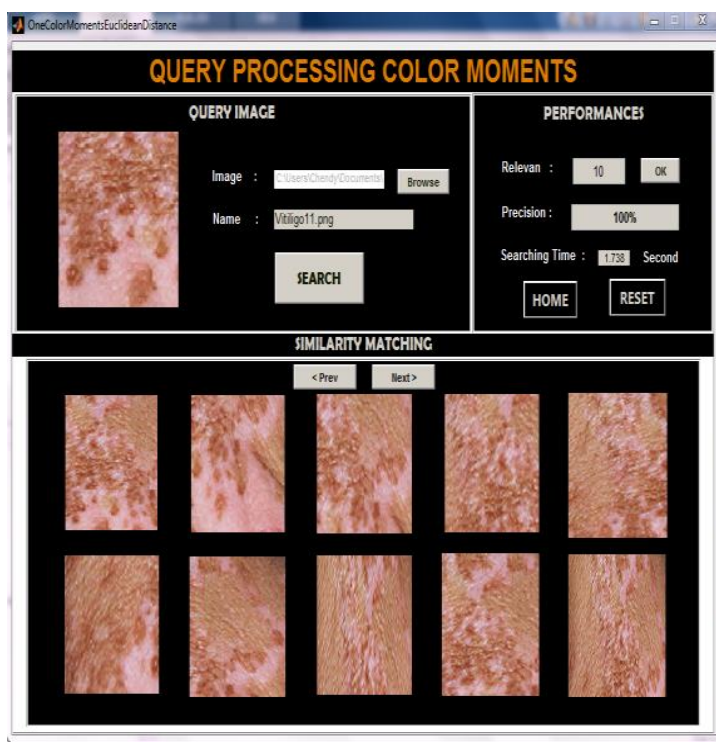

(b)

Gambar 7. (a) Tampilan Hasil Pengujian pada Metode Co-occurrence Matrix (b) Tampilan Hasil

Pengujian pada Metode Color Moments

CBIR Penyakit Kulit dengan Metode Co-occurrence Matrix dan Color Moments (Ni Putu Chendy Widya Santi D) 


\subsection{Analisa}

Analisa pengujian sistem dilakukan untuk mengetahui pengaruh keakurasian sistem dari Metode Co-occurrence Matrix dan Metode Color Moments. Hasil dari pengujian percobaan dari sistem menggunakan citra uji ditampilkan pada Tabel 2 dan Tabel 3.

Tabel 2. Table Akurasi Metode Color Moments

\begin{tabular}{|c|c|c|c|c|c|c|}
\hline No & Kelas & $\begin{array}{l}\text { Citra Uji } \\
\text { Pertama }\end{array}$ & $\begin{array}{c}\text { Citra Uji } \\
\text { Kedua }\end{array}$ & $\begin{array}{c}\text { Citra Uji } \\
\text { Ketiga }\end{array}$ & $\begin{array}{l}\text { Citra Uji } \\
\text { Keempat }\end{array}$ & Rata-rata \\
\hline 1 & Acne & $100 \%$ & $100 \%$ & $100 \%$ & $100 \%$ & $100 \%$ \\
\hline 2 & Acropustulosis & $100 \%$ & $100 \%$ & $100 \%$ & $100 \%$ & $100 \%$ \\
\hline 3 & Alopecia & $100 \%$ & $80 \%$ & $90 \%$ & $80 \%$ & $87.5 \%$ \\
\hline 4 & Dermatitis & $100 \%$ & $100 \%$ & $100 \%$ & $100 \%$ & $100 \%$ \\
\hline 5 & Hemangioma & $70 \%$ & $70 \%$ & $100 \%$ & $90 \%$ & $82.5 \%$ \\
\hline 6 & Herpes & $100 \%$ & $100 \%$ & $90 \%$ & $90 \%$ & $95 \%$ \\
\hline 7 & Ichthyosis & $100 \%$ & $100 \%$ & $100 \%$ & $100 \%$ & $100 \%$ \\
\hline 8 & Molluscum & $90 \%$ & $90 \%$ & $90 \%$ & $90 \%$ & $90 \%$ \\
\hline 9 & Nummular & $100 \%$ & $100 \%$ & $100 \%$ & $100 \%$ & $100 \%$ \\
\hline 10 & Skin Tag & $100 \%$ & $100 \%$ & $100 \%$ & $100 \%$ & $100 \%$ \\
\hline 11 & Urticaria & $90 \%$ & $80 \%$ & $90 \%$ & $90 \%$ & $87.5 \%$ \\
\hline 12 & Vittiligo & $100 \%$ & $100 \%$ & $100 \%$ & $100 \%$ & $100 \%$ \\
\hline \multicolumn{6}{|c|}{ Rata-rata akurasi Metode Color Moments } & $95.2 \%$ \\
\hline
\end{tabular}

Tabel 3. Tabel Akurasi Metode Co-occurrence Matrix

\begin{tabular}{llllllr}
\hline No & \multicolumn{1}{c}{ Kelas } & $\begin{array}{c}\text { Citra Uji } \\
\text { Pertama }\end{array}$ & $\begin{array}{c}\text { Citra Uji } \\
\text { Kedua }\end{array}$ & $\begin{array}{c}\text { Citra Uji } \\
\text { Ketiga }\end{array}$ & $\begin{array}{c}\text { Citra Uji } \\
\text { Keempat }\end{array}$ & Rata-rata \\
\hline 1 & Acne & $10 \%$ & $20 \%$ & $20 \%$ & $20 \%$ & $17.5 \%$ \\
2 & Acropustulosis & $80 \%$ & $80 \%$ & $20 \%$ & $70 \%$ & $62.5 \%$ \\
3 & Alopecia & $100 \%$ & $80 \%$ & $80 \%$ & $100 \%$ & $90 \%$ \\
4 & Dermatitis & $70 \%$ & $70 \%$ & $50 \%$ & $60 \%$ & $62.5 \%$ \\
5 & Hemangioma & $30 \%$ & $40 \%$ & $30 \%$ & $20 \%$ & $30 \%$ \\
6 & Herpes & $90 \%$ & $90 \%$ & $100 \%$ & $100 \%$ & $95 \%$ \\
7 & Ichthyosis & $20 \%$ & $80 \%$ & $70 \%$ & $70 \%$ & $60 \%$ \\
8 & Molluscum & $40 \%$ & $60 \%$ & $60 \%$ & $40 \%$ & $50 \%$ \\
9 & Nummular & $30 \%$ & $90 \%$ & $100 \%$ & $90 \%$ & $77.5 \%$ \\
10 & Skin Tag & $100 \%$ & $90 \%$ & $60 \%$ & $20 \%$ & $67.5 \%$ \\
11 & Urticaria & $100 \%$ & $10 \%$ & $70 \%$ & $60 \%$ & $60 \%$ \\
12 & Vittiligo & $20 \%$ & $20 \%$ & $20 \%$ & $20 \%$ & $20 \%$ \\
\hline \multicolumn{7}{r}{ Rata-rata akurasi Metode Co-occurrence Matrix } \\
\hline \multicolumn{7}{l}{}
\end{tabular}

Hasil pengujian sistem dari Metode Co-occurrence Matrix dan Metode Color Moments yang diperoleh ditampilkan melalui grafik perbandingan akurasi dari kedua metode seperti pada Gambar 8. 


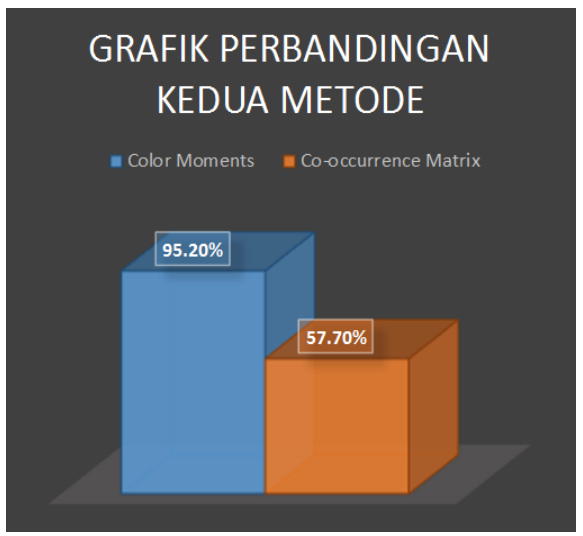

Gambar 8. Grafik Perbandingan Kedua Metode

Gambar 8 merupakan grafik perbandingan Metode Co-occurrence Matrix dan Metode Color Moments. Berdasarkan grafik perbandingan kedua metode dapat disimpulkan bahwa tingkat akurasi menggunakan Metode Co-occurrence Matrix lebih tinggi daripada menggunakan Metode Color Moments.

\section{Kesimpulan}

Sistem Content Based Image Retrieval pada Citra Penyakit Kulit dengan Metode CoOccurrence Matrix dan Metode Color Moments menggunakan tiga nilai warna yaitu Hue, Saturation dan Value. Perhitungan ciri warna dan ciri tekstur pada salah satu citra penyakit kulit telah berhasil dihitung menggunakan Metode Co-occurrence Matrix dan Metode Color Moments. Hasil pengujian Metode Color Moments dan Metode Co-occurrence Matrix menunjukkan akurasi sebesar $95.2 \%$ dan $57.7 \%$.

\section{Daftar Pustaka}

[1] I. P. B. Krisnawan, I. K. G. D. Putra, and I. P. A. Bayupati, "Sistem Pakar Diagnosa Penyakit Kulit dan Kelamin dengan Metode Certainty Factor dan Fuzzy Logic," Jurnal Merpati, vol. 2, no. 3, pp. 351-360, 2014.

[2] P. T. K. Putra and N. K. A. Wirdiani, "Pengolahan Citra Digital Deteksi Tepi untuk Membandingkan Metode Sobel, Robert dan Canny," Jurnal Merpati, vol. 2, no. 2, pp. 253-261, 2014.

[3] N. N. Budiasih, "Content-Based Image Retrieval Menggunakan Walshlet Pyramid dan Gabor Wavelet," Lontar Komputer, vol. 4, no. 3, pp. 312-323, 2013.

[4] A. Padmo and Murinto, "Segmentasi Citra Batik Berdasarkan Fitur Tekstur Menggunakan Metode Filter Gabor dan K -Means Clustering," Jurnal Informatika, vol. 10, no. 1, pp. 1173-1179, 2016.

[5] M. Stricker and M. Orengo, "Similarity of Color Images," SPIE Conferences Storage Retrieval Image Video Databases III, vol. 2420, pp. 381-392, 1995.

[6] K. G. D. Putra, "A New Technique Based on PIFS Code for Image Retrieval System," Applied Mathematical Sciences, vol. 7, no. 120, pp. 5957-5967, 2013.

[7] R. D. S. Torres and A. X. Falcão, "Content-Based Image Retrieval: Theory and Applications," RITA, vol. 13, no. 2, pp. 161-185, 2006.

[8] N. L. W. S. Rahayu G, "Deteksi Batik Parang Menggunakan Fitur Co-Occurrence Matrix dan Geometric Moment Invariant dengan Klasifikasi KNN," Lontar Komputer, vol. 7, no. 1, pp. 715-725, 2016.

[9] I. P. G. Budisanjaya, I. K. G. D. Putra, and I. N. S. Kumara, "Identification of Nitrogen Status in (Brassica Juncea L.) using Color Moment, GLCM and Backpropagation Neural Network," International Symposium Agricultural Biosystem Engineering, 2013.

[10] F. Astutik, "Sistem Pengenalan Kualitas Ikan Gurame dengan Wavelet, PCA, Histogram HSV dan KNN," Lontar Komputer, vol. 4, no. 2, pp. 336-346, 2013. 